\title{
Importance of chlamydial antibodies in acute salpingitis in central Africa
}

\author{
ERIC FROST,* MICHEL COLLET, $\dagger$ JAN RENIERS, $\ddagger$ ANNICK LECLERC,* BERNARD \\ IVANOFF* AND ANDRÉ MEHEUS, $\ddagger$ \\ From the *International Centre for Medical Research of Franceville, (CIRMF), the $\dagger$ Department of Obstetrics \\ and Gynecology, Franceville Hospital, Franceville, Gabon, and the $\ddagger$ Department of Epidemiology and \\ Community Medicine, University of Antwerp, Antwerp, Belgium
}

SUMMARY Of 35 women with acute salpingitis on laparoscopy, $86 \%$ had chlamydial antibodies at a titre of $1 / 16$ or higher and $49 \%$ at a titre of $1 / 512$ or higher.

Geometric mean titres of chlamydial antibodies correlated significantly with a laparoscopic observation of chronic salpingitis $(p<0.001)$, with a history of infertility $(p<0.05)$, and with severe inflammation $(p<0 \cdot 10)$, but not with a history of salpingitis or a positive cervical culture for Chlamydia trachomatis. In the subgroup of infertile women, the geometric mean titre of antibodies to chlamydiae correlated significantly with the presence of chronic salpingitis $(p<0.005)$.

These data indicate that chlamydial infections play a major part in salpingitis and infertility in central Africa. In this area, which is known as the "infertility belt", programmes to control chlamydial infections should be implemented.

\section{Introduction}

Salpingitis and its sequelae, tubal infertility and extrauterine pregnancy, are a public health problem in most African countries. ${ }^{12}$ Earlier studies indicated that the gonococcus is a major pathogen in salpingitis in Africa. ${ }^{34}$ Recent data from Gabon show that Chlamydia trachomatis is at least as important as the gonococcus in salpingitis and infertility. ${ }^{5}$ Cervical chlamydial infection has been shown to be as common as gonorrhoea in African women. ${ }^{6} 7$

Controversy remains about the aetiological diagnosis of acute salpingitis. Cultural studies of endocervical samples cannot establish with certainty the aetiology of tubal infection. Isolation rates from tubal or cul-de-sac specimens are usually low and do not always correlate with each other or with endocervical cultures. ${ }^{89}$

The use of serological tests to establish a diagnosis of chlamydial salpingitis has been suggested, but many

Address for reprints: Professor A Meheus, Department of Epidemiology and Community Medicine, University of Antwerp, Universiteitsplein 1, 2610 Antwerp, Belgium.

Accepted for publication 25 September 1986. pitfalls exist in the interpretation of the results. ${ }^{910}$ In this study we analysed determinants of positive results to chlamydial serology tests in patients with acute salpingitis in central Africa. An overall clinical and microbiological analysis of patients with salpingitis is the subject of a separate report.

\section{Patients and methods}

We included in this study 35 consecutive women with laparoscopically confirmed acute salpingitis. All were examined at the gynecology and obstetrics department of the Franceville hospital in Gabon by the same investigator (MC). Minimum criteria for diagnosing acute salpingitis were swollen fallopian tubes with congested red tubal mucosa and the presence of purulent or seropurulent exudate. ${ }^{9}$ During laparoscopy pelvic inflammation was graded as mild, moderately severe, or severe, and the presence or absence of adhesions (chronic salpingitis) was noted. Each patient was questioned regarding a history of salpingitis and her fertility status. She was considered to be infertile if, in the absence of contraception, she had not had a live birth in the previous three years or an abortion, a stillbirth, or an ectopic pregnancy in the previous two years. 
Endocervical swabs were taken and cultured for Neisseria gonorrhoeae and $C$ trachomatis. Blood samples were taken, and serum chlamydial antibodies were measured by a simplified microimmunofluorescence test using an antigen belonging to the $B, D$, and $E$ serotypes $^{12}$ and anti-human IgG, IgA, and IgM labelled with fluorescein (Institut Pasteur, Paris).

The correlation of chlamydial serology test results with history of salpingitis, fertility status, endocervical chlamydia cultures, severity of acute inflammation, and presence or absence of chronic salpingitis was evaluated by a one way parametric analysis of variance. $^{13}$

\section{Results}

Of the 35 women with laparoscopically confirmed acute salpingitis, $18(51 \%)$ had moderately severe and 17 (49\%) had severe pelvic inflammation (table). In 19 (54\%) women an additional diagnosis of chronic salpingitis was made. A history of salpingitis was reported by 13 women $(37 \%)$, and $25(71 \%)$ were considered to be infertile. Endocervical cultures for $C$ trachomatis were positive in nine $(26 \%)$. Chlamydial antibodies at a titre of $1 / 16$ or higher were found in 30 women $(86 \%)$ and at a titre of $1 / 512$ or higher in $17(49 \%)$

We calculated the geometric mean titres of antichlamydial antibody for subgroups of several variables and the significance of the difference

TABLE Correlation between geometric mean titres (GMT) of chlamydial antibody with selected variables in patients with acute salpingitis

\begin{tabular}{|c|c|c|c|}
\hline Variable & No & $G M T$ & Difference \\
\hline $\begin{array}{l}\text { Acute inflammation: } \\
\text { Moderately severe } \\
\text { Severe }\end{array}$ & $\begin{array}{l}18 \\
17\end{array}$ & $\begin{array}{l}1 / 114 \\
1 / 327\end{array}$ & \}$_{p}<0.1$ \\
\hline $\begin{array}{l}\text { Chronic salpingitis: } \\
\text { Absent } \\
\text { Present }\end{array}$ & $\begin{array}{l}16 \\
19\end{array}$ & $\begin{array}{l}1 / 64 \\
1 / 476\end{array}$ & \}$_{p}<0.001$ \\
\hline $\begin{array}{l}\text { History of salpingitis: } \\
\text { Absent } \\
\text { Present }\end{array}$ & $\begin{array}{l}22 \\
13\end{array}$ & $\begin{array}{l}1 / 193 \\
1 / 186\end{array}$ & NS \\
\hline $\begin{array}{l}\text { Fertility status: } \\
\text { Fertile } \\
\text { Infertile }\end{array}$ & $\begin{array}{l}10 \\
25\end{array}$ & $\begin{array}{l}1 / 69 \\
1 / 286\end{array}$ & \}$_{p}<0.05$ \\
\hline $\begin{array}{l}\text { Chlamydial cervical cultu } \\
\text { Negative } \\
\text { Positive }\end{array}$ & $\begin{array}{r}26 \\
9\end{array}$ & $\begin{array}{l}1 / 154 \\
1 / 348\end{array}$ & \} NS \\
\hline $\begin{array}{l}\text { Infertile women: } \\
\text { No chronic salpingitis } \\
\text { Chronic salpingitis }\end{array}$ & $\begin{array}{r}8 \\
17\end{array}$ & $\begin{array}{l}1 / 70 \\
1 / 556\end{array}$ & \}$_{p}<0.005$ \\
\hline $\begin{array}{l}\text { No chronic salpingitis: } \\
\text { Fertile } \\
\text { Infertile }\end{array}$ & $\begin{array}{l}8 \\
8\end{array}$ & $\begin{array}{l}1 / 59 \\
1 / 70\end{array}$ & \} NS \\
\hline
\end{tabular}

between both titres for each subgroup (table). Geometric mean titres of chlamydial antibodies were significantly higher in women with a laparoscopic observation of chronic salpingitis than in those without $(p<0.001)$, and in those with a history of infertility than in those without $(p<0.05)$, whereas borderline significance was found for the difference between severe and moderately severe inflammation $(p<0 \cdot 1)$. We observed no significant difference between those with and without a history of salpingitis or between those with positive and negative cervical chlamydial cultures. To evaluate separately possible correlations between geometric mean titres of antibody to chlamydiae and either chronic salpingitis or fertility status, these variables were analysed independently in this cohort of women with acute salpingitis. In infertile women mean titres correlated strongly with the presence of chronic salpingitis $(p<0.005)$. In women who did not have chronic salpingitis the difference in the mean titres between fertile and infertile women was not significant.

\section{Discussion}

In recent years many studies have used chlamydial serology tests to assess the role of $C$ trachomatis in acute salpingitis. ${ }^{101415}$ As with other serological diagnoses, a fourfold rise in titre between two consecutive serum samples is accepted as indicative of a causal relation between salpingitis and chlamydial infection..$^{8914} \mathrm{~A}$ single IgG titre of $1 / 512$ or higher has been proposed as an alternative indicator of chlamydial aetiology. ${ }^{15}$ Indeed, significant differences in chlamydial antibody titres were found in case control studies of patients with acute salpingitis even when up to $80 \%$ of the population had some antibodies to $C$ trachomatis. ${ }^{14}$

Our data indicate clearly that high chlamydial antibody titres in patients with acute salpingitis correlated significantly with concomitant chronic salpingitis. High antibody titres probably reflect chronic infection in such patients. Chlamydial salpingitis often has a mild, yet protracted, clinical course. Many women therefore do not seek medical advice, which results in chronic infection and high chlamydial antibody titres. This mild clinical picture contrasts sharply with the severity of pelvic inflammation observed during laparoscopy. In the gynecology clinic in Franceville $45 \%$ of patients with acute salpingitis are classified as having severe pelvic inflammation (Collet $\mathrm{M}$, unpublished data).

Chronic salpingitis may be exacerbated by acute salpingitis, be a contributing factor in acute salpingitis of mixed aetiology or, alternatively, not be related to the episode of acute salpingitis. A single high titre of chlamydial antibody cannot, therefore, be considered 
to indicate current acute salpingitis of chlamydial origin. On the other hand, as we found a significant correlation between chlamydial serology and chronic salpingitis, our data indicate that $\boldsymbol{C}$ trachomatis must be an important cause of salpingitis in central Africa. Furthermore, a fairly strong correlation was observed between chronic salpingitis and infertility in this and other studies. ${ }^{89}$ This again indicates that chlamydial infections probably play a major part in salpingitis and infertility in central Africa. Case control studies in women with salpingitis or with tubal or non-tubal infertility ${ }^{16}$ might elucidate further the role of chlamydiae in salpingitis and its sequelae in central Africa.

This study was supported by contract No TSD-M-329B(B) of the European Economic Community.

\section{References}

1. Muir DG, Belsey MA. Pelvic inflammatory disease and its consequences in the developing world. Am J Obstet Gynecol 1980;138:913-28.

2. Cates W, Farley TMM, Rowe PJ. Worldwide patterns of infertility: is Africa different? Lancet 1985; i:596-8.

3. Carty MJ, Nzioki JM, Verhagen AR. The role of gonococcus in acute pelvic inflammatory disease in Nairobi. East Afr Med J 1972;49:376-9.

4. Grech ES, Everett JV, Mukasa F. Epidemiological aspects of acute pelvic inflammatory disease in Uganda. Trop Doct 1973;3:123-7.

5. Meheus A, Reniers J, Collet M, et al. Chlamydia trachomatis in women with acute salpingitis and infertility in Central Africa. In: Oriel D, Ridgway G, Schachter J, Taylor-Robinson D, Ward M, eds. Chlamydial infections. Proceedings of the sixth international symposium on human chlamydial infection, 1986. Cambridge: Cambridge University Press, 1986:241-4.

6. Mabey DCW, Whittle HC. Genital and neonatal chlamydial infection in trachoma endemic area. Lancet 1982;i:300-1.

7. Piot $\mathbf{P}$, Meheus A. Epidémiologie des maladies sexuellement transmissibles dans les pays en développement. Ann Soc Belge Med Trop 1983;63:87-110.

8. Mårdh P-A, Svensson L. Chlamydial salpingitis. In: Mårdh P-A Möller BR, Paavonen J, eds. Chlamydia trachomatis in genital and related infections. Stockholm: Almqvist and Wiksell, 1982:64-72.

9. Weström L, Mårdh P-A. Salpingitis. In: Holmes KK, Mårdh P-A, Sparling PF, Wiesner PJ, eds. Sexually transmitted diseases. New York: McGraw-Hill, 1984:615-32.

10. Treharne JD, Ripa KT, Mårdh P-A, Svensson L, Weström L, Darougar S. Antibodies to Chlmaydia trachomatis in acute salpingitis. British Journal of Venereal Diseases 1979;55:269.

11. Simmons PD, Forsey T, Thin RN, et al. Antichlamydial antibodies in pelvic inflammatory disease. British Journal of Venereal Diseases 1979;55:419-21.

12. Wang SP, Grayston JT, Kuo CC, Alexander ER, Holmes KK. Serodiagnosis of Chlamydia trachomatis infection with the microimmunofluorescence test. In: Hobson D, Holmes KK, eds. Non-gonococcal urethritis and related infections. Washington DC: American Society for Microbiology, 1977:237-48.

13. Snedecor GW, Cochran WG. Statistical methods. Ames, Iowa, USA: Iowa State University Press, 1967.

14. Thompson SE, Washington E. Epidemiology of sexually transmitted Chlamydia trachomatis infections. Epidemiol Rev 1983;5:96-123.

15. Kristensen GB, Bollerup AC, Lind $\mathrm{K}$, et al. Infections with Neisseria gonorrhoeae and Chlamydia trachomatis in women with acute salpingitis. Genitourin Med 1985;61:179-84.

16. Mabey DCW, Ogbaselassie G, Robertson JN, Heckels JE, Ward ME. Tubal infertility in the Gambia: chlamydial and gonococcal serology in women with tubal occlusion compared with pregnant controls. Bull WHO 1985;63:1107-13. 